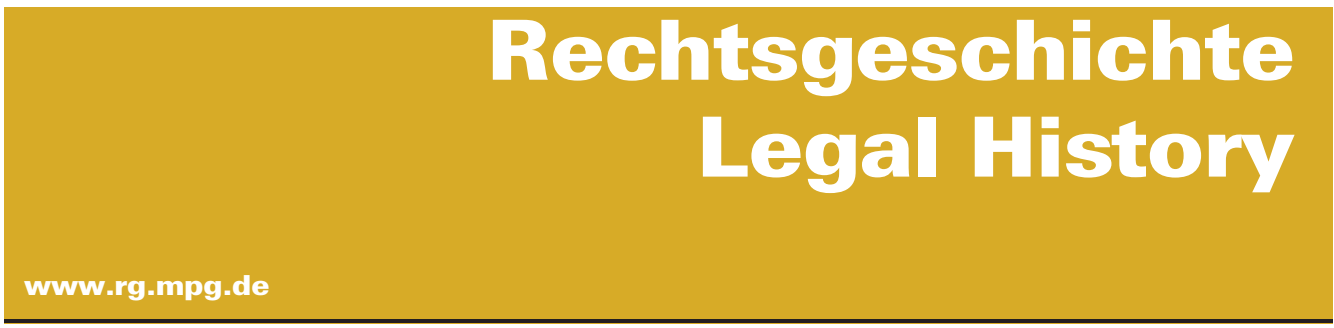

http://www.rg-rechtsgeschichte.de/rg22

$\operatorname{Rg} 222014 \quad 150-157$

Zitiervorschlag: Rechtsgeschichte - Legal History Rg 22 (2014)

http://dx.doi.org/10.12946/rg22/150-157

\title{
Jean-Louis Halpérin
}

Transplants of European Normativity in India and in Japan: a Historical Comparison 


\section{Abstract}

What can we learn from a comparison between legal transplants in modern India and Japan? Are they so strong differences between a colonized territory and an always independent country? The process of reception of Western law appears to be very similar in India and in Japan, as a global importation of legal institutions and schemes. The limits for the reception of Western models have their origins in sociological and political factors rather than in cultural ones. The question of legal education is crucial until today and also involves the American model. One has to study, as an important element of differentiation, the evolution of legal writing in the two countries. 


\section{Jean-Louis Halpérin Transplants of European Normativity in India and in Japan: a Historical Comparison}

For the history of legal transplants of Western origin, Japan has been considered as a model or a kind of ideal-type from a long time. ${ }^{1}$ Since 1868 , and the beginning of the Meiji era, Japan was seen as a big extra-European country that was not colonized, but whose Government chose under the authority of the emperor to modernize its legal system through massive imitations of European laws, especially the French and the German codifications or the Prussian constitution. The voluntary action of the Meiji Government (decided after different studies travels and investigations in the most powerful European countries) and the eclectic inspirations of Japanese lawyers suppose a true "policy« about legal transplants that has been continued through generations and renewed in the $20^{\text {th }}$ century under two different factors: the occupation of Japan by the United States after World War II (1945-1952), which has triggered important borrowings of American law (notably constitutional, corporation and labour law) and the development of a strong tradition of comparative law among Japanese law scholars, who are currently linked with the United States, Germany and France.

The case of India has been generally studied as a different one. First, because it was a colonized country, in which the British rulers could impose their justice and their conceptions of law. It could be said that India was forced to become a »common law country « and that Indian lawyers had no other choice during the $19^{\text {th }}$ century and the first half of the $20^{\text {th }}$ century than to adopt common law traditions. It is well known that Gandhi and many other leaders of the Indian national movement studied law in England and were called to the English Bar. Whereas legal formants of Western origin were translated in Japanese, English became and remained until today the official language of Indian law. Second, as an apparent contradiction, the decision taken by the British colonizers to keep personal laws - first the ones of Muslim and Hin$\mathrm{du}$ people, then of the Christian, Parsi and Jew minorities - has given the feeling that the substratum of indigenous laws has been respected by the colonizers. If the rulers used common law institutions (like the jury or the English family law), have not the colonized kept their traditional law, without the influence of legal transplants? However, this point of view is today criticized and nearly abandoned. It has been proved that, from the end of the $18^{\text {th }}$ century, British lawyers (like William Jones) have »manipulated « Hindu and Muslim sources and partly invented an Hindu legal tradition through the translation of the Manu Code and its recognition as a »law book«, or through the establishment of an Anglo-Muhammadan Law (which was different from Muslim law). ${ }^{2}$ The importance of British legislation, and even codification, in India has been also re-evaluated as something very special in the common law context. ${ }^{3}$

If one considers today India and Japan as two great Asian countries through their population (more than one billion people in India, more than 123 millions in Japan), their powerful economy (the third world ranking for Japan, the ninth for India) and their extraordinary living culture (for example in literature and pictures), it is noteworthy that these two legal systems were and remain deeply westernized, the first one with a British common law dominant influence, the second one with a »civil law« (French and German) print. In these two countries a great part of what is qualified as »legal «, from the constitution to courts practice through the legal vocabulary and lawyers dressing, is of European origin. It can even be asked if the "concept of law«, as it is nowadays understood in India and in Japan, is not a Western invention transplanted in these Asian territories. This assertion can appear provocative, but if one admits that every society (or polity) was not en-

\footnotetext{
1 Riesenhuber (2007).

2 Bhattacharyya-Panda (2008).

3 Halpérin (2010).
} 
dowed with a legal system, it can be controversial to decide when something as law was invented in India and in Japan. There are many doubts about the oldness of indigenous law in Japan and in India: there is no evidence that the Manu's Code (Manu Smrti) and other Dharmasastras were legal norms and the same question can be asked also about the 604 "Seventeen-article constitution" of Japan. For a great part, law was developed in both countries through foreign influences: the one of Chinese law in Japan (the 702 Taiho Code and the 718 Yoro Code were inspired by the Chinese Tang Code) and the one of Muslim Law in India. Furthermore, in Japan as in India, this traditional law was in a phase of decay when the European pressure developed on both countries. A comparison of European normativity transplantation is, according to me, meaningful between Japan and India: it could show how two different historical contexts have known rather similar process of legal transplants and in which fields the massive transplants of the $19^{\text {th }}$ century have been limited or, on the contrary, revived in the last decades.

I. Two different situations, a similar process of global reception of Western law

The historical contexts in which the European normativity could be transplanted in India and in Japan are characterized by some clear differences. The European legal influence in India, beginning in sixteenth and seventeenth centuries factories created in some harbours by the Portuguese, the Dutch, the French and the British colonizers, blossomed with the British rule after the end of the Seven Years War (1763), that reduced the ambitions of French colonizers to a few trading posts. Of course, it was a big enterprise of colonization that began with the 1757 diwan granted by the Mughal emperor to the East India Company in order to collect taxes in Bengal, Bihar and Orissa. But it could be said that the legal sovereignty of the emperor remained under the Company rule (or Raj) until the Indian Rebellion of 1857. In 1858, the Mughal dynasty came to an end and the British Raj transformed India in a crown colony. Nevertheless, Princely States kept a relative autonomy under the British suzerainty.
On the contrary, Japan emperors succeeded to maintain the independence of their country and, since the beginning of the Meiji era in 1868, were the leaders of the deep reforming movement, including the borrowing of Western legal formants. But one can also consider that Japan was subjected to a military and political pressure from the Western world and especially the American since the 1854 Perry expedition. The Government of the Shogun was constrained to sign unequal treaties (with some privileges of judicial nature for foreign merchants) with the US and European countries. The legal transplants policy, notably with the development of a modern judiciary and the process of law codification, was an indispensable means to prove that Japan was now endowed with a true (and fair) legal system and to obtain the revision of these treaties. Is it necessary to remind us that Japan was occupied by the US from 1945 to 1952 and that this military administration had a great role in writing the 1946 Constitution and reforming the main Codes? If Japan was never colonized, the country was not always truly "sovereign $«$.

Another feature that makes the Japanese and the Indian situations rather similar is the crisis of their legal systems in $18^{\text {th }}$ century and $19^{\text {th }}$ century. In Japan, the shogun Government (bakufu) controlled only one part of the territory and could not really impose the respect of its rules to the powerful daymios. This feudal context has meant for a long time a decline of legal regulations (penal laws from Chinese inspiration) in favour of the social normativity of chivalry codes. During the $18^{\text {th }}$ century, there was an attempt (provoked by NeoConfucianism influences) to reinforce the legal corpus (the 1742 Code called Kujikata-Osadamega$t i)$. But these laws were kept secret and the shogun has no real means to force daymios courts to apply these texts. ${ }^{4}$ Japan knew a curious situation of relatively important developments of litigation (in the biggest towns where litigants lived in courts inns and obtained here a kind of legal advice from innkeepers), without a true legal order or organized lawyers. ${ }^{5}$

In the same time, the Mughal emperor encountered also great difficulties to make the Muslim penal law applied in his territories and probably tolerated the use of social customs (especially 
Hindu ones) that were not enshrined in legal texts. ${ }^{6}$ In South India, the main source of court decisions was custom: whereas in $14^{\text {th }}-16^{\text {th }}$ century Kerala, the Dharmasastras were never quoted, ${ }^{7}$ the Manu Smrti was known in the $18^{\text {th }}$ century courts of the Marathas kingdom. ${ }^{\mathbf{8}}$ Generally speaking, there was no class of true lawyers in what is called »traditional Hindu law «, 9 a normative system that cannot be qualified as »legal« without discussion. Courts decided case by case without taking in consideration any normative text. ${ }^{10}$ The fact that the 1757 diwan let the civil justice department to the East India Company in Bengal, Bihar and Orissa, then that the emperor did not react against Warren Hastings policy to suppress the penal competences of the kazis (cadis) in the 1770 s shows that the control of the legal system was no more a political target for the last Mughal rulers.

It would be exaggerated to consider that there was a "vacuity « of law in India before the development of the British colonization and in Japan before the Meiji era. But one can argue that there was not a sophisticated legal system (as in China or in some Muslim countries) supported by a group of professional lawyers or by intellectual developments concerning the legal science. At the beginning of the Meiji era, the great Japanese theorist Yuchiki Fukuzawa could write that three things lack in Japan in comparison with the Western World: science, commerce and law. ${ }^{\mathbf{1 1}}$

In both countries, the main question about Western legal transplants was not a choice between common law and civil law models, but the adoption (by direct force or by indirect pressure) of the whole legal structure of the European Modern States based on the concept (which is always ours) of »rationalized law« (to use Max Weber's vocabulary). It is true that India could not make a choice between common law and civil law models because of the domination of English colonizers (with the exception of French or Portuguese trading posts, where civil law continued to be applied until today), whereas the Japan Government decided, after some preliminary investigations (Japanese students were sent to Great Britain and called to the Bar), that civil law systems were easier to be transplanted (with the ready-made codes) than common law ones (with the traditional importance of case law rooted in historical foundations). But, in both territories, law appeared first as a global Western product. It is noteworthy that Roman law was taught and used as well in India (William Jones wrote a Digest of Hindu Law and, later, Roman law was a matter of examination for future barristers) as in Japan (where the influence of Roman law is linked with the one of the German Civil Code). ${ }^{\mathbf{1 2}}$ Besides private law (and its different structure in common law and civil law countries), the law of procedure (which was characterized by many points of contact between Great Britain, France and Germany, for example about the jury system or the rights of defence), penal law, constitutional law, administrative organs and regulations, later intellectual property or labour law were modelled in India and in Japan according general Western patterns that could not be assigned specially to civil or common law countries. The legal impact of the development of taxation, census, army, local administrations or elections (specially after World War I) was another effect of a massive transplant of European features of the Modern State. Again, from 1945 to 1952, the US occupation did not mean the transformation of a civil law country in a common law one: the structure of the codes was kept and many institutions (for example in penal procedure) remained very different from the American model. It was rather the question to implement in Japan the democratic and WelfareState that has been reshaped in America by the New Deal and inspired also many reforms in European countries (for example in France and in Germany).

It can be said that all the "formal « characters of European normativity, as they were specially developed in the $18^{\text {th }}$ century and $19^{\text {th }}$ century, were transplanted in India and in Japan. At the first rank, one thinks at the codes or at the rationalized legislation in penal and civil matters. It is the matter of the five Japanese codes, the number of which is modelled under the French model: the Penal and Penal procedure codes (the first ones in
6 FISCH (1983).

7 Davis (2002) 83, 119, 149 and 204.

8 Gune (1953) 69.

9 ROCHeR (1968).

10 Michaels (2010) 71.
11 Fukizawa, Yukichiy (1872-76) 38;

Encouragement of Learning (2012)

28.

12 KNÜTEL (2004). 
1882, the new Penal Code in 1907), the Code of Civil Procedure (1890), the Civil Code (Minpo, 1896-1898) and the Commercial Code (1899). For the preparation of the Civil Code (under the direction of the French professor Boissonade from 1873 to 1892), as well as for the Commercial Code (under the direction of the German professor Roessler), it is noteworthy that Japanese customs were collected and studied by the drafters of the Code. But these customs appear divided or uncertain (in family matters they were translated in English by Wigmore) and finally the Japanese writers of the codes decided not to use them. Some Japanese scholars, like Naoki Kanayama, consider today that there is absolutely nothing that can be qualified »traditionally Nippon « in these codifications. $^{13}$

More surprisingly, the British colonizers have also used the codification process in India to impose similar rules to all their subjects: the 1858 Code of Civil Procedure, the 1860-1862 Indian Penal Code, ${ }^{14}$ the 1861 Code of Criminal Procedure, to which one must add the Indian Contract Act (1872), the Indian Evidence Act (1872), the Specific Relief Act (1877), the Easement Act (1882), the Bills of Exchange Act (1882), the Transfer of Property Act (1882), or the Indian Trust Act (1882), which are all developed statutory laws (there are 238 sections in the Indian Contract Act, 167 in the Indian Evidence Act) very similar to specialized codes. The British colonizers considered that codification was a bad thing in Great Britain, but a good means to impose (as a form of legal despotism) Western rules (often inspired by French models) to indigenous peoples.

With the codification process it is also a rationalized case law, known through official or private law reports, which was transplanted in Japan and in India during the $19^{\text {th }}$ century. Private law reports about decisions of Presidency or Company courts were printed in India since the years $1810 \mathrm{~s}$ and 1820s. Then, they were favoured by the colonial Government after the establishment of the High Courts in 1862 and semi official collections, as the Law Reports of the Bombay High Court, appeared regularly in the 1870s. In Japan the decisions of the Great Court of Cassation (Daishinin established in 1875 according to the French model) were also published at the end of the $19^{\text {th }}$ century. It is another formal feature of European legal systems that was thus transplanted.

Beginning in Japan with the 1889 Constitution (following the 1851 Prussian model) and in colonial India with the 1919 and 1935 Government of India Acts, modern constitutionalism was also borrowed from Western countries. Constitutional law, which is now in force in Japan or in India, is based for the first country on a 1946 text largely written by American experts, and for the second one on the longest constitution of the world voted in 1950 by the Constituent Assembly after a detailed study of many foreign constitutions. Both constitutions have adopted the British modelled parliamentary government, combined with the American style of judicial review. Despite the various divergences in the content of these constitutional laws, the form of the constitution (as the fundamental norm of the country) is again a legal transplant from the Western world.

To finish with this summary of the global reception of the Western concept of law in India and in Japan, one has to remember that English is until today the language of courts and lawyers and that new Japanese words were specially created (and inserted in the codes) to express Western legal notions that were unknown in the traditional language until the Meiji era. ${ }^{15}$

II. Which limits and which changes in the reception of Western normativity?

As for any legal transplant, the outcomes of this reception of Western normativity in Japan and in India are difficult to be evaluated in the longue durée. One has been so accustomed to consider as normal the keeping of the Indian Penal Code or of the Minpo until today that their history seems to have lost any link with the one of European law. Through process of »Indianization« or »Japaniza-
13 Kanayama, Naoki (to be published). 14 SKuY (1998).

15 An important role was the one of RinSho Mitsukuri who translated the French codification in Japanese in 1875. The Japanese Codes of the Meiji era were written in Chinese writing style with the katakana rendering. Recently they have been rewritten in biragana to make them more accessible to common people. 
tion « many legal institutions of Western origin have been acculturated in their Asiatic context. On the other hand, the question remains if the reception of European normativity has not be limited to an apparent superstructure or reinterpreted in an American way.

About the limits of the reception of European normativity, the current debates are focusing on the great difference between a country with so many peoples (from a religious, ethnic and social point of view) as India and the so-called »homogeneous society« of Japan. In legal terms it seems clear that the reception of European transplants would be easier in a unitary structure (with the same rules for all citizens) than in a federal one, especially with the keeping of personal (religious) laws. Is not the impossibility until today to achieve the promise of the Indian constitution about a »uniform civil code « the proof of a pluralistic legal order combining Asiatic cultures (especially in Hindu and Muslim law) with the one inherited from the British colonization? ${ }^{\mathbf{1 6}}$

Nevertheless, some »cultural« obstacles to a complete reception of Western normativity have been emphasized also in the case of Japan. Among the most frequently quoted arguments, the Japanese distrust towards law, ${ }^{\mathbf{1 7}}$ the importance of the indigenous concept of social duties (giri), the resistance of traditional family patterns (with a minor status for married women, a rather weak number of divorces, a very small percentage of illegitimate children), the small rate of litigation and the preference to arranged settlements (between relatives, neighbours or in industrial relations) would be clues that law has not acquired until today the status of "supremacy" (towards other means of regulation) in the treatment of social conflicts. ${ }^{18}$ Legal history helps to correct these stereotypes about the "national spirit « (kokumin-sei in Japan) and to introduce chronological and social nuances: the rate of litigation was relatively high during the inter-wars period, ${ }^{\mathbf{1 9}}$ the »traditional« family (with it own titles about civil status) has been upset by the implementation of the Minpo and it is difficult anywhere to estimate the domain of law in social regulations. Japanese courts and lawyers were and are not façade institutions, without any impact on the society: the recent debates about the re-introduction of the criminal jury (practised only between 1923 and $1943)^{20}$ and about legal education (which has concerned a great part of the Japanese elite) show that many Japanese people can be interested in legal questions.

If one compares the Japanese situation with the Indian ones, cultural factors appear to have been more important in India to limit the reception of European normativity. Especially, the keeping of personal laws as rooted in religious and social traditions as Hindu law and Muslim law has made family law a kind of citadel of resistance against the »legal individualism « (and the egalitarian principle in favour of women) what we link with European transplants. The difficulties that British then Indian rulers have encountered to curtail polygamy, the effects of the dower institution in the bad situation of married women (towards their mother in law), the practise of burning widows (sati), the unequal treatment of women in succession law have been exemplified as cultural obstacles to a deep anchored reception of Westernized institution like the »special marriage (between members of different religious communities), the right to divorce or the patrimonial capacity of women. Furthermore, the survival of the caste system, despite its prohibition through the 1950 constitution, has created great difficulties to transplant directly the European concept of equality before the law.

Here again, the historical comparison allows developing a more complex analysis. First, British colonizers have constructed personal laws (as some effects of the caste-system) according European categories (from the departure, in considering Hindu Dharmasastras and Muslim fiqh as laws). There is not a simple opposition between a "traditional indigenous « law and »modern transplanted « rules. Then, European transplants could have an impact in the longue durée: the recognition of Christian and Muslim divorces or the distrust of colonizers towards polygamy have facilitated the 1954-1955 reforms in Hindu law, prohibiting polygamy between Hindus and introducing the

16 Herrenschmidt (2009).

17 Noda (1976) 159.

18 DeAn (2002).

19 Haley (2006) 27.

20 Ortolani (2010). 
institution of divorce (that has recently grown up, notably in big cities, as an example of the Westernization of the way of life in India). One has to take account also of political (rather than cultural) factors in the failure of some Western transplants as the criminal jury abandoned in India in the 1960s (because it was one symbol of the unequal colonial justice). ${ }^{\mathbf{2 1}}$ If the problems engendered by the caste-system are very specific to India, the fight against discriminations is also a question in Japan (concerning Burakumin or Ainu people), which was impossible to solve with the $19^{\text {th }}$ century European legal technique. Cultural factors appear less pregnant that political issues and sociological transformations in the metamorphosis of legal transplants of Western origin.

Rather than this global comparison between two complex societies in constant evolution, it would be more fruitful to develop studies about the competition between European and American normativity, especially in the field of legal education. Since the Perry expedition, the relationship between Japan and the US has always been crucial in the Westernization of Japan. If American law (a concept that was not so easy to understand, outside the constitutional sphere, during the $19^{\text {th }}$ century) was not a model for the Meiji reformers, there were already some links between Japanese and American lawyers. For translating the French codes (and the word »droit « in the meaning of right with the neologism kenri), Mitsukuri used a Chinese translation of Wheaton's Elements of international law. ${ }^{22}$ Tocqueville was also translated in Japanese at the end of the $19^{\text {th }}$ century and could influence Japanese lawyers about American Democracy. Later, Izutaro Suehiro, one of the pioneers of legal sociology in Japan, studied at Chicago University at the end of World War I and introduced the American case method in the Japanese law teaching. $^{23}$

Of course, the main stream of US legal influence happened in Japan after World War II, especially during the period of American occupation (1945-1952). It concerned first the constitution, human rights and judicial review and, here again, a comparison is possible with the voluntary borrowings of the 1950 India constitution to the models of the Supreme Court and of the Bill of Rights. But many other fields of Japanese law - as corporations, competition, labour standards, criminal law and family law - were concerned by the 1945-1952 reforms inspired by American authorities. It is noteworthy that American experts did not try to convert this civil law country in a common law one (the structure of the codes was kept and even the inquisitorial criminal process was just amended to favour the rights of defence) and that some aspects of this US-modelled legislation were abandoned or transformed after 1952 (for example about the control of the equity market, or with the case law protecting workers against unfair firing ${ }^{24}$ ).

What seems the most important today, in India as in Japan, is the attractive force of the American model of law schools on legal education in both countries. The case of Japan is the most spectacular. Since the end of the nineteenth century, Japan has developed a dense web of Law Faculties (more than one hundred as public or private institutions), which was conceived according the European (German and French) model: a 4 years courses study led to the degree of Bachelor of Law. Since 1947, all future judges, attorneys and advocates had to enter (through a difficult competition, a numerus clausus being decided by the State) the Legal Training and Research Institute (Shibo Kenshusho). This very elitist system has meant that many graduates ${ }^{25}$ of the Law Faculty (especially outside the biggest universities in Tokyo and Kyoto) did not become practising lawyers (a phenomenon that did not prevent many managers or politicians to be educated in Law Faculties). In 2004, the system was reformed in order to increase the number of advocates that was considered too small (9000 in 1970, less than 15000 at the beginning of the 2000s) for sustaining the international competition. 74 Law Schools were created to prepare post-graduates (coming from the Law Faculties or other undergraduate studies) for entering the Legal Training and Research Institute (which is called also the Bar Examination). The American model was clearly imitated through the name of these new institutions (for a great part linked with the old Law Faculties), the institution of an admission test or the policy to develop legal clinics for preparing future lawyers to work in big law firms. For different reasons (notably the economic crisis), the numerical targets assigned to

21 Kolsky (2010); Halpérin (2012) 104.24 Gould (1987).

22 Vienna (2007) 231

23 Матsumoto (2007) 123.
25 Around 45,000 and 50,000 students passed the degree each year. 
the reform have not been reached and the rate of success (from $48 \%$ to $25 \%$ ) has constantly diminished, provoking controversial debates in Japan. It is noteworthy that, in this competition between the European and the American model of legal education, Law Faculties remained more open to comparative and foreign law than the competition prepared by the Law Schools, which is centred on the study of the Japanese Six Codes (the collection of the five codes and of the constitution, called Roppo).

In India, the traditional system (beginning during the British colonization) was a three years study in universities (the greatest ones have law colleges affiliated to them) or in law colleges, all checked by the Bar Council of India (the degree made the graduates eligible for becoming advocates). This system (a combination of the British and of the American ones) was completed, since the $1980 \mathrm{~s}$ (the first one was the National Law School of India University on Bangalore), by the one of law universities offering a more complete curriculum (integrating other social sciences) during five years. It can be said that it is paradoxically a European continental model that was the main source of inspiration of these law universities. Nevertheless NLS has also used moot courts and other aspects of the American case method. The nowadays debates about legal education in India (about a bad assessment in 2001 for NLS or the creation of a national Bar examination in 2010) and in Japan are showing how the globalization has renewed older schemes about the reception of Western normativity, which is no more limited to European normativity.

India and Japan are two complex examples, developed in a long-term history, of massive »legal transplants«, that are based on different forms of authority: the authority of European colonizers, the one of European (and American) Great Powers, the one of European elites, the one of prestigious Western universities or law schools. ${ }^{26}$ On the other side (the side of the "borrowers" of these legal transplants), India and Japan have constituted two legal fields, or two successions of different configurations of legal fields (among Indian and Japanese judges, advocates, professors ...), in which indigenous lawyers had to react (according to collective policies or individual patterns) towards Western transplants. There are new legal histories (varying in different periods) to develop and to write about these processes of acculturation and transformation of a set of norms (including social practices and cultural values) of European origin. Researches about legal writing in Japan and in India during the $19^{\text {th }}$ and the $20^{\text {th }}$ centuries have to take place in a program about the impact of European normativity, in order to know if and how a Japanese or an Indian doctrine has transformed European conceptions of law.

\section{Bibliography}

- Bhattacharyya-Panda, Nandini (2008), Appropriation and Invention of Tradition. The East India Company and Hindu Law in Early Colonial Bengal, New Delhi

- Davis, Donald R. (2002), The Boundaries of Law: tradition, scustoms a and politics in late medieval Kerala, Ph. D. Austin (Texas)

- Dean, Meryll (2002), The Japanese Legal System, London

- Encouragement of Learning (2012), translated by David A. Dilworth, Tokyo

- Fisch, Jörg (1983), Cheap Limbs and Dear Limbs: The British Transformation of the Bengal Criminal Law, Wiesbaden

- Fukizawa, Yukichiy (1872-76), Gakumon no susume, Tokyo 2009

- Gune, Vithal Trimbak (1953), The Judicial System of the Marathas, Ponna

- Gould, William B. (1987), Japan's Reshaping of American Labor Law, Cambridge (MA)

- Haley, John Owen (2006), The Spirit of Japanese Law, Athens (Georgia)

- Halpérin, Jean-Louis (2010), Western Legal Transplants and India, in: Jindal Global Law Review 2/1, 14-40

- Halpérin, Jean-Louis (2012), Portraits du droit indien, Paris

- Herrenschmidt, Olivier (2009), The Indians' Impossible Civil Code, in: European Journal of Sociology 2, 309-347 http:// dx.doi.org/10.1017/S0003975609990154

- Kanayama, Naoki (to be published), Le caractère non-occidental du Minpo: mythe ou réalité, in: Brunet, Pierre et al. (eds), Rencontre franco-japonaise autour du transfert de concepts, Paris, 23-30 
- Kitagawa Zentaro et al. (eds.) (2007), The Identity of German and Japanese Civil Law in Comparative Perspectives, Berlin

- Knütel, Rolf (2004), Das Japanische Zivilgesetzbuch und das Römische Recht, in: Knütel, Rolf, Nishimura Shigeo (eds.), Hundert Jahre Japanisches Zivilgesetzbuch, Köln, Berlin, München, 131-184

- Kolsky, Elisabeth (2010), Colonial Justice in British India, Cambridge

- Matsumoto, Tsuneo (2007), Anglo-American Law Research, in: Kitagawa (2007) 120-149

- Michaels, Alex (2010), The Practice of classical Hindu Law, in: Lubin, Timothy et al. (eds.), Hinduism and Law: an Introduction, Cambridge, $58-77$

- Noda, Yoshiniko (1976), Introduction to Japanese Law, Tokyo

- Ortolani, Andrea (2010), Reflection on Citizen Participation in Criminal Justice in Japan: Jury, Saiban-in System and Legal Reform, in: Zeitschrift für Japanisches Recht, 153-176

- Riesenhuber, Karl (2007), On the Identity of Japanese Civil Law in a European Perspective, in: Kitagawa (2007) 223-248

- Rocher, Ludo (1968), 'Lawyers in Classical Hindu Law, in: Law \& Society Review 3, n² 2/3, 383-402 http://dx.doi.org/ $10.2307 / 3053008$

- SkuY, David (1998), Macaulay and the Indian Penal Code of 1862: The Myth of the Inherent Superiority and Modernity of the English Legal System in the Nineteenth Century, in: Modern Asian Studies 32, 513-557 http://dx.doi.org/10.1017/ S0026749X98003035

- Steenstrup, Carl (1996), A History of Law in Japan until 1868, Leiden

- Vienna, Maria Gioia (2007), Human Rights in Japan, in: Pföstl, Eva (ed.), Human Rights and Asian Values, Roma, 209-285

- Watson, Alan (1993), Legal Transplants. An Approach to Comparative Law, Athens (Georgia)

- Wollschläger, Christian (1997), Historical Trends of Civil Litigation, in: Baum, Harald (ed.), Japan: Economic Success and Legal System, Berlin, New York, 89-142 